\title{
Amycolatopsis marina sp. nov., an actinomycete isolated from an ocean sediment
}

\author{
Jiang Bian, ${ }^{1,2,3}$ † Yan Li, ${ }^{4} \dagger$ Jian Wang, ${ }^{1,2,3}$ † Fu-Hang Song, ${ }^{1}$ Mei Liu, ${ }^{1}$ \\ Huan-Qin Dai, ${ }^{1}$ Biao Ren, ${ }^{1,3}$ Hong Gao, ${ }^{1}$ Xinling Hu, ${ }^{1}$ Zhi-Heng Liu, ${ }^{1}$ \\ Wen-Jun Li ${ }^{2,4}$ and Li-Xin Zhang ${ }^{1,2,5,6}$ \\ ${ }^{1}$ Institute of Microbiology, Chinese Academy of Sciences, Beijing 100101, PR China \\ ${ }^{2}$ South China Sea Institute of Oceanology, Chinese Academy of Sciences, Guangzhou 510301, \\ PR China \\ ${ }^{3}$ Graduate University of the Chinese Academy of Sciences, Beijing 100049, PR China \\ ${ }^{4}$ Yunnan Institute of Microbiology, Yunnan University, Kunming, Yunnan 650091, PR China \\ ${ }^{5}$ Guangzhou Institute of Biomedicine and Health, Chinese Academy of Sciences, Guangzhou \\ 510663, PR China \\ ${ }^{6}$ SynerZ Pharmaceuticals Inc., Lexington, MA 02421, USA
}

Correspondence

Li-Xin Zhang

zhanglixin@im.ac.cn

Wen-Jun Li

wjli@ynu.edu.cn

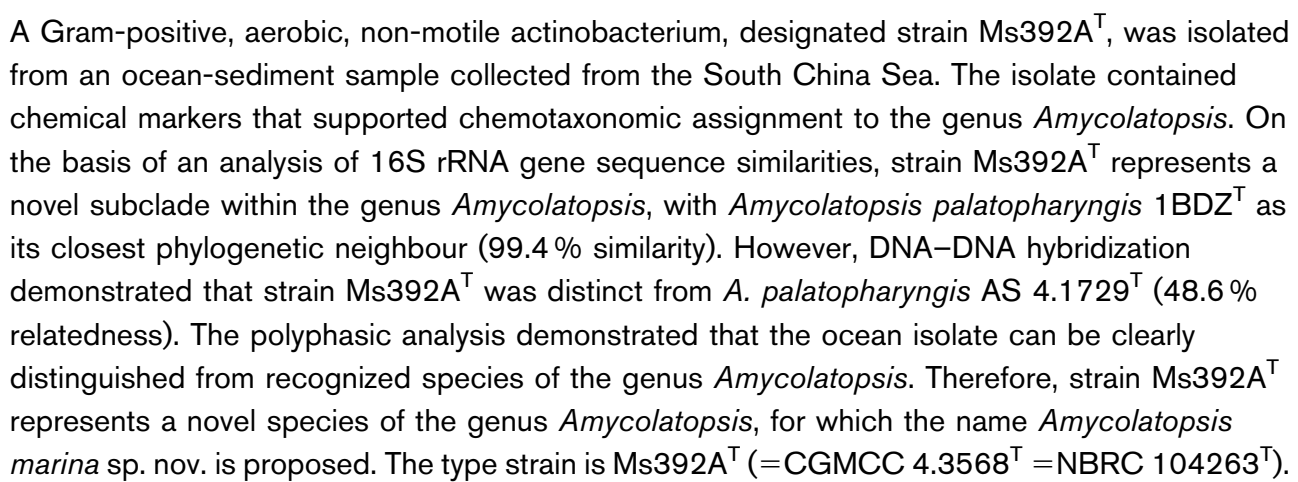

The genus Amycolatopsis, classified as belonging to the family Pseudonocardiaceae (Embley et al., 1988; Warwick et al., 1994), was proposed by Lechevalier et al. (1986) for aerobic, amycolate, nocardioform actinomycetes and is well defined as a result of chemotaxonomic characterization (Lechevalier et al., 1986; Henssen et al., 1987; Mertz \& Yao, 1993; Yassin et al., 1993) and phylogenetic analyses based on the comparison of 16S rRNA gene sequences (Embley et al., 1988; Warwick et al., 1994). The members of the genus Amycolatopsis are Gram-positive, non-acidfast, non-motile actinomycetes that form branched vegetative hyphae that undergo fragmentation into rod-like and squarish elements. In addition, they are represented chemotaxonomically by the following features: wall chemotype IV (meso-diaminopimelic acid, arabinose and galactose in cell-wall hydrolysates), a tetrahydrogenated menaquinone with nine isoprene units $\left[\mathrm{MK}-9\left(\mathrm{H}_{4}\right)\right]$ as the major menaquinone, a phospholipid pattern of type II

†These authors contributed equally to this work.

The GenBank/EMBL/DDBJ accession number for the 16S rRNA gene sequence of strain Ms392A ${ }^{\top}$ is EU329845. sensu Lechevalier et al. (1977) (phosphatidylethanolamine as a diagnostic phospholipid), fatty acid profiles that include complex mixtures of saturated and branched-chain acids and the absence of mycolic acids. The members of this genus have DNA G+C contents in the range 66$73 \mathrm{~mol} \%$.

At the time of writing, the genus Amycolatopsis comprises 38 recognized species, most of which were isolated from various terrestrial environments (Goodfellow et al., 2001; Kim et al., 2002; Saintpierre-Bonaccio et al., 2005; Lee et al., 2006; Tan et al., 2006a; Groth et al., 2007; Carlsohn et al., 2007) or clinical material (Labeda et al., 2003; Huang et al., 2004). On the basis of chemotaxonomic and morphological markers (Kim \& Goodfellow, 1999) and analyses using genus-specific oligonucleotide primers (Tan et al., 2006b), Amycolatopsis strains were separated from members of the other genera classified within the family Pseudonocardiaceae. Recently, there has been an explosion of information about novel bioactive compounds isolated from members of the genus Amycolatopsis (Demain \& Zhang, 2005; Zhang et al., 2005). In an effort to explore the 
relatively untapped potential of members of this genus and investigate potential applications for their secondary metabolites (Zhang et al., 2007), we attempted to isolate and identify strains from the South China Sea.

Strain Ms $392 \mathrm{~A}^{\mathrm{T}}$ was isolated using the following procedure. Fresh deep-ocean sediment samples were collected in the South China Sea and kept at $4{ }^{\circ} \mathrm{C}$ for isolation as soon as possible. Serial dilutions of sample suspensions were transferred onto the selective isolation medium (SM1; Tan et al., 2006b) for the genus Amycolatopsis and incubated at $28{ }^{\circ} \mathrm{C}$ for 4 weeks.

Strain Ms $392 \mathrm{~A}^{\mathrm{T}}$ was cultivated on ISP 2, ISP 3, ISP 4 and ISP 5 media (Shirling \& Gottlieb, 1966) at $28{ }^{\circ} \mathrm{C}$. Spore chains were observed for colonies grown using the coverslip technique of Kawato \& Shinobu (1959). Morphological characteristics were examined by using light microscopy (CX41; Olympus) and scanning electron microscopy (S-570; Hitachi). Morphological features were observed on ISP 2 and ISP 4 media at $28{ }^{\circ} \mathrm{C}$. The phenotypic properties of the isolate were consistent with its classification within the genus Amycolatopsis. The whitish aerial mycelium, which was produced only on ISP 2 and ISP 4, formed rod-like mycelial fragments. No diffusion pigments were produced on any of the media tested.

Physiological and biochemical characteristics of strain $\mathrm{Ms}_{398 \mathrm{~A}^{\mathrm{T}}}$ are given in Table 1 and in the species description. Carbohydrate utilization was tested using ISP 9 (Shirling \& Gottlieb, 1966) as the basal medium with filter-sterilized compounds at a final concentration of $1 \%$ $(\mathrm{w} / \mathrm{v})$. Urease activity was determined by checking for a colour change in Bacto urea broth (Difco). The production of $\mathrm{H}_{2} \mathrm{~S}$ was tested on peptone iron agar (Difco). Nitrate reduction, gelatin liquefaction and degradation of elastin and starch were examined by using previously described methods (MacFaddin, 1980). Decomposition of adenine, hypoxanthine, casein, DL-tyrosine and xanthine was examined by using the methods of Gordon et al. (1974). Antibiotic susceptibility was investigated as described by Groth et al. (2004), using antibiotic discs (Himedia). Growth over a range of temperatures $\left(4-60{ }^{\circ} \mathrm{C}\right)$, $\mathrm{pH}$ values and $\mathrm{NaCl}$ concentrations was determined on ISP 2 medium. The $\mathrm{pH}$ range and optimum for growth and the tolerance of $\mathrm{NaCl}$ were examined as described by Tang et al. (2003). Catalase activity was determined by assessing bubble production in $3 \%(\mathrm{v} / \mathrm{v}) \mathrm{H}_{2} \mathrm{O}_{2}$, and oxidase activity was determined using a $1 \%(\mathrm{w} / \mathrm{v})$ solution of tetramethylp-phenylenediamine (Kovács, 1956).

The procedures used for the identification of cell-wall amino acids and sugars in whole-cell hydrolysates were those described by Staneck \& Roberts (1974). Menaquinones were extracted by using the method of Collins et al. (1977) and were analysed by means of HPLC, as described by Tamaoka et al. (1983). Polar lipids were extracted as described by Minnikin et al. (1979) and identified by using two-dimensional TLC and spraying with specific reagents (Collins \& Jones, 1980). Biomass for
Table 1. Differential phenotypic characteristics of strain Ms392 $\mathrm{A}^{\top}$ and its closest phylogenetic neighbour, A. palatopharyngis AS $4.1729^{\top}$

Data were taken from this study or from Huang et al. (2004). +, Positive; W, weakly positive; -, negative; $\mathrm{R}$, resistant; $\mathrm{s}$, sensitive.

\begin{tabular}{|c|c|c|}
\hline Characteristic & $\begin{array}{l}\text { A. marina sp. } \\
\text { nov. Ms } 392 \mathrm{~A}^{\mathrm{T}}\end{array}$ & $\begin{array}{c}\text { A. palatophar- } \\
\text { yngis AS } \\
4^{1729^{\mathrm{T}}}\end{array}$ \\
\hline \multicolumn{3}{|c|}{$\begin{array}{l}\text { Utilization as sole carbon } \\
\text { source of: }\end{array}$} \\
\hline$(+)$-L-Arabinose & - & $\mathrm{W}$ \\
\hline$(+)$-L-Rhamnose & + & - \\
\hline$(+)$-Maltose & + & - \\
\hline$(+)$-Raffinose & - & $\mathrm{W}$ \\
\hline \multicolumn{3}{|l|}{ Decomposition of: } \\
\hline L-Lysine & - & + \\
\hline Starch & w & - \\
\hline \multicolumn{3}{|l|}{ Production of: } \\
\hline Catalase & + & - \\
\hline Urease & - & $\mathrm{w}$ \\
\hline Nitrate reductase & - & + \\
\hline \multicolumn{3}{|c|}{ Drug susceptibility/resistance } \\
\hline Rifampicin & $\mathrm{R}$ & s \\
\hline Erythromycin & s & $\mathrm{R}$ \\
\hline Sulfamethoxazole & $\mathrm{R}$ & S \\
\hline Kanamycin & $\mathrm{R}$ & s \\
\hline Carbenicillin & s & $\mathrm{R}$ \\
\hline Clarithromycin & $\mathrm{R}$ & s \\
\hline Cephalothin & s & $\mathrm{R}$ \\
\hline \multicolumn{3}{|l|}{ Growth at/with: } \\
\hline $45^{\circ} \mathrm{C}$ & $\mathrm{W}$ & - \\
\hline $12 \% \mathrm{NaCl}$ & $\mathrm{w}$ & - \\
\hline $\mathrm{pH} 10.0$ & - & $\mathrm{W}$ \\
\hline
\end{tabular}

quantitative fatty acid analysis of strain $\mathrm{Ms} 398 \mathrm{~A}^{\mathrm{T}}$ was prepared by scraping growth from TSB agar plates that had been incubated for 7 days at $28{ }^{\circ} \mathrm{C}$. Fatty acids were extracted, methylated and analysed using the MIDI (Microbial Identification) system. The cell-wall diamino acid in the peptidoglycan layer of strain $\mathrm{Ms} 392 \mathrm{~A}^{\mathrm{T}}$ was meso-diaminopimelic acid, the major sugars in the cell wall were arabinose and galactose (cell-wall chemotype IV according to Lechevalier \& Lechevalier, 1980) and the predominant isoprenoid quinones were tetrahydrogenated menaquinones with eight and nine isoprene units. The phospholipids included diphosphatidylglycerol, phosphatidylmethylethanolamine, phosphatidylethanolamine, phosphatidylinositol, phosphatidylglycerol and phosphatidylinositol mannoside. The major fatty acids were iso- $\mathrm{C}_{16: 0} \quad(40.35 \%)$ and iso- $\mathrm{C}_{16: 0} \quad 2-\mathrm{OH} \quad(11.42 \%)$. Others fatty acids that occurred in smaller amounts were $\mathrm{C}_{17: 1}$ cis9 $(8.61 \%), \mathrm{C}_{16: 1}$ cis $9(7.79 \%), \mathrm{C}_{16: 0}(7.08 \%)$, $\mathrm{C}_{17: 0}(4.89 \%)$, iso- $\mathrm{C}_{17: 0}(3.46 \%), \mathrm{C}_{15: 0}(2.91 \%)$, iso$\mathrm{C}_{16: 1} \mathrm{H}(2.66 \%)$, anteiso- $\mathrm{C}_{17: 0}(2.28 \%), \mathrm{C}_{15: 1} \mathrm{~B}(1.63 \%)$, iso- $\mathrm{C}_{15: 0} \quad(1.50 \%), \quad 10$-methyl $\mathrm{C}_{16: 0} \quad(1.39 \%), \mathrm{C}_{18: 0}$ 
$(1.35 \%), \mathrm{C}_{18: 1}$ cis $9(0.97 \%)$, iso- $\mathrm{C}_{14: 0}(0.90 \%)$ and iso- $\mathrm{C}_{18: 0}(0.81)$.

Extraction of genomic DNA and PCR amplification and $16 \mathrm{~S}$ rRNA gene sequencing were carried out as described previously (Li et al., 2007). An almost-complete $16 \mathrm{~S}$ rRNA gene sequence (1485 bp) was generated for the novel isolate. Preliminary comparison of this sequence against those in the GenBank database indicated that the novel isolate was closely related to the members of the family Pseudonocardiaceae. A phylogenetic analysis was performed using the software packages PHYLIP (Felsenstein, 1993) and MEGA, version 3.1 (Kumar et al., 2004), after multiple alignment of the data using CLUSTAL_X (Thompson et al., 1997). Distances (using distance options according to Kimura's two-parameter model; Kimura, 1980, 1983) were calculated and clustering was performed with the neighbour-joining method (Saitou \& Nei, 1987). Bootstrap analysis (based on 1000 resamplings) was used to evaluate the tree topology of the neighbour-joining data (Felsenstein, 1985).

The phylogenetic analysis (Fig. 1) indicated that isolate $\mathrm{Ms} 392 \mathrm{~A}^{\mathrm{T}}$ formed a distinct clade within the radiation encompassing the members of the genus Amycolatopsis, and revealed that the isolate was most closely associated with Amycolatopsis palatopharyngis $1 \mathrm{BDZ}^{\mathrm{T}}$ within a separate cluster. The $16 \mathrm{~S}$ rRNA gene sequence similarities between strain Ms392A $\mathrm{A}^{\mathrm{T}}$ and Amycolatopsis species with validly published names were below $97.0 \%$, except for $A$. palatopharyngis $1 \mathrm{BDZ}^{\mathrm{T}}$, which showed $99.4 \%$ similarity (corresponding to 9 differences over 1427 locations).

To determine whether strain Ms392 $\mathrm{A}^{\mathrm{T}}$ represents a distinct species of the genus Amycolatopsis, DNA-DNA hybridizations were performed by applying the method of He et al. (2005) with five replications for each sample. Strain Ms $392 A^{\mathrm{T}}$ displayed low DNA-DNA reassociation with $A$. palatopharyngis AS $4.1729^{\mathrm{T}}$ (mean value $48.6 \%$ ). The result is far below the cut-off point recommended for the circumscription of bacterial genomic species by Wayne et al. (1987). The G+C content of the DNA was determined by using the HPLC method (Mesbah et al., 1989) and a mean value of $70.1 \mathrm{~mol} \%$ was obtained.

Features that serve to differentiate strain Ms392A ${ }^{\mathrm{T}}$ from its closest phylogenetic neighbour, A. palatopharyngis AS $4.1729^{\mathrm{T}}$, are shown in Table 1. Thus, in conclusion, genotypic, chemotaxonomic and phenotypic data demonstrate that strain Ms $392 \mathrm{~A}^{\mathrm{T}}$ represents a novel species of the genus Amycolatopsis, for which the name Amycolatopsis marina sp. nov. is proposed.

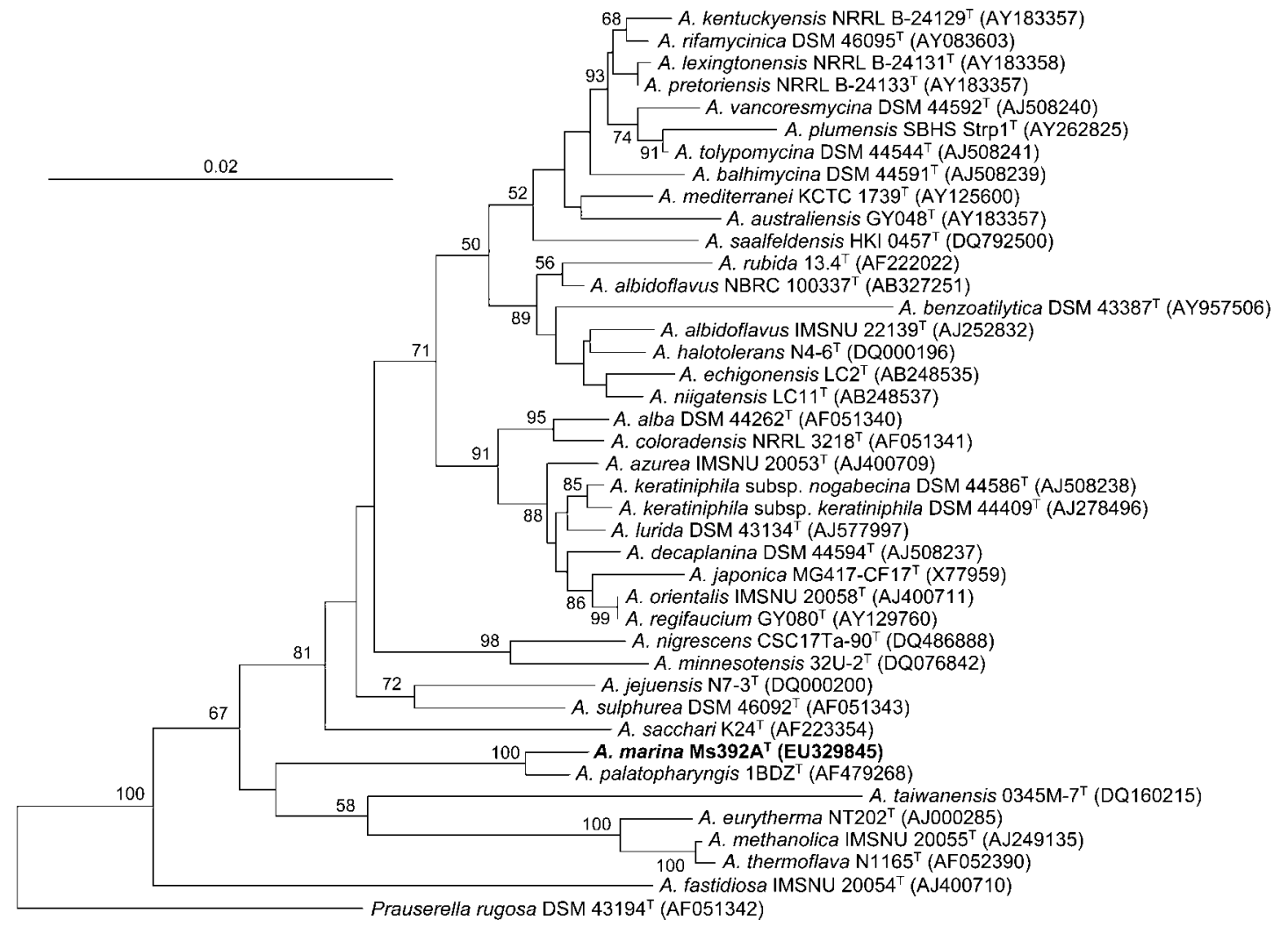

Fig. 1. Neighbour-joining phylogenetic tree, based on almost-complete $16 \mathrm{~S}$ rRNA gene sequences, showing the position of strain Ms392 $\mathrm{A}^{\top}$ within the radiation of the genus Amycolatopsis. Bootstrap percentages (based on 1000 resamplings) are shown at nodes. Bar, 0.02 substitutions per nucleotide position. 


\section{Description of Amycolatopsis marina sp. nov.}

Amycolatopsis marina (ma.ri' na. L. fem. adj. marina of the sea, marine).

Cells are Gram-positive, aerobic and non-motile and produce white aerial mycelium sparsely on ISP 2 agar medium. The branched yellow to yellow-brown substrate mycelium fragments into rod-like elements. No diffusion pigments are produced on any of the media tested. Catalase-positive and oxidase-negative. Negative for urease and negative for reduction of nitrate to nitrite. $\mathrm{H}_{2} \mathrm{~S}$ is not produced. Growth occurs between $\mathrm{pH} 6.0$ and 9.0, between 10 and $45{ }^{\circ} \mathrm{C}$ and between 0.5 and $12 \% \mathrm{NaCl}$, but not above $45{ }^{\circ} \mathrm{C}$ or above $12 \% \mathrm{NaCl}$. The optimum growth $\mathrm{pH}$, temperature and $\mathrm{NaCl}$ are $7.0-8.0,28{ }^{\circ} \mathrm{C}$ and $5 \%$ $\mathrm{NaCl}$. Resistant to rifampicin, amikacin, carbenicillin, tobramycin, kanamycin, clarithromycin and penicillin G (each at $30 \mu \mathrm{g}$ ), but sensitive to gentamicin, novobiocin, streptomycin, doxycycline, acetylspiramycin, carbenicillin, midecamycin, minocycline, cephalothin and chloramphenicol. (+)-D-Fructose, $(+)$-D-galactose, $(+)$-cellobiose, myo-inositol, $(+)$-L-rhamnose salicin, $(+)$-maltose, $(+)$-D-mannitol and $(+)$-trehalose are utilized as carbon sources, but sorbitol, (+)-D-lactose, dextrin, arabinose, $(+)$-raffinose and (-)-sucrose are not. Decomposes gelatin, hypoxanthine, xanthine, allantoin and starch, but not L-tyrosine or casein. Cell-wall hydrolysates contain meso-diaminopimelic acid, arabinose and galactose. MK$9\left(\mathrm{H}_{4}\right)(79 \%)$ is the predominant menaquinone; MK- $8\left(\mathrm{H}_{4}\right)$ $(13 \%)$ is also present. The phospholipids comprise diphosphatidylglycerol, phosphatidylmethylethanolamine, phosphatidylethanolamine, phosphatidylinositol, phosphatidylglycerol and phosphatidylinositol mannoside. The major cellular fatty acids are iso- $\mathrm{C}_{16: 0}$ and iso- $\mathrm{C}_{16: 0} 2$ $\mathrm{OH}$. The DNA $\mathrm{G}+\mathrm{C}$ content of the type strain is $70.1 \mathrm{~mol} \%$.

The type strain, Ms $392 \mathrm{~A}^{\mathrm{T}}\left(=\mathrm{CGMCC} 4.3568^{\mathrm{T}}=\mathrm{NBRC}\right.$ $104263^{\mathrm{T}}$ ), was isolated from an ocean-sediment sample collected in the South China Sea.

\section{Acknowledgements}

We are grateful to Yu-Guang Zhou and Yu-Hua Xin (China General Microbiological Culture Collection Center, Beijing, PR China) for technical support. This work was supported, in part, by a grant from the National 863 Project (2006AA09Z402 and 2007AA09Z443), the Chinese Academy of Sciences Innovation Projects (KSCXZ-YW-G013) and the 973 Project (2007CB707802). L.-X.Z. received funding from the Hundred Talents Program and W.-J. L. was supported by the Program for New Century Excellent Talents in University.

\section{References}

Carlsohn, M. R., Groth, I., Tan, G. Y. A., Schütze, B., Saluz, H. P., Munder, T., Yang, J., Wink, J. \& Goodfellow, M. (2007). Amycolatopsis saalfeldensis sp. nov., a novel actinomycete isolated from a medieval alum slate mine. Int J Syst Evol Microbiol 57, $1640-1646$.
Collins, M. D. \& Jones, D. (1980). Lipids in the classification and identification of coryneform bacteria containing peptidoglycans based on 2,4-diaminobutyric acid. J Appl Bacteriol 48, 459-470.

Collins, M. D., Pirouz, T., Goodfellow, M. \& Minnikin, D. E. (1977). Distribution of menaquinones in actinomycetes and corynebacteria. $J$ Gen Microbiol 100, 221-230.

Demain, A. L. \& Zhang, L. (2005). Natural products and drug discovery. In Natural Products: Drug Discovery and Therapeutic Medicine, pp. 3-32. Edited by L. Zhang \& A. L. Demain. Totowa, NJ: Humana Press.

Embley, T. M., Smida, J. \& Stackebrandt, E. (1988). The phylogeny of mycolate-less wall chemotype IV actinomycetes and the description of Pseudonocardiaceae fam. nov. Syst Appl Microbiol 11, 44-52.

Felsenstein, J. (1985). Confidence limits on phylogenies: an approach using the bootstrap. Evolution 39, 783-791.

Felsenstein, J. (1993). PHYLIP (phylogeny inference package), version 3.5c. Distributed by the author. Department of Genome Sciences, University of Washington, Seattle, USA.

Goodfellow, M., Kim, S. B., Minnikin, D. E., Whitehead, D., Zhou, Z. H. \& Mattinson-Rose, A. D. (2001). Amycolatopsis sacchari sp. nov., a moderately thermophilic actinomycete isolated from vegetable matter. Int J Syst Evol Microbiol 51, 187-193.

Gordon, R. E., Barnett, D. A., Handerhan, J. E. \& Pang, C. H.-N. (1974). Nocardia coeliaca, Nocardia autotrophica, and the nocardin strain. Int J Syst Bacteriol 24, 54-63.

Groth, I., Rodriguez, C., Schütze, B., Schmitz, P., Leistner, E. \& Goodfellow, M. (2004). Five novel Kitasatospora species from soil: Kitasatospora arboriphila sp. nov., $K$. gansuensis sp. nov., $K$. nipponensis sp. nov., $K$. paranensis sp. nov. and $K$. terrestris sp. nov. Int J Syst Evol Microbiol 54, 2121-2129.

Groth, I., Tan, G. Y. A., Gonzales, J. M., Laiz, L., Carlsohn, M. R., Schütze, B., Wink, J. \& Goodfellow, M. (2007). Amycolatopsis nigrescens sp. nov., an actinomycete isolated from a Roman catacomb. Int J Syst Evol Microbiol 57, 513-519.

He, L., Li, W., Huang, Y., Wang, L. M., Liu, Z. H., Lanoot, B. J., Vancanneyt, M. \& Swings, J. (2005). Streptomyces jietaisiensis sp. nov., isolated from soil in northern China. Int J Syst Evol Microbiol 55, 1939-1944.

Henssen, A., Kothe, H. W. \& Kroppenstedt, R. M. (1987). Transfer of Pseudonocardia azurea and "Pseudonocardia fastidiosa" to the genus Amycolatopsis, with emended species description. Int J Syst Bacteriol 37, 292-295.

Huang, Y., Paściak, M., Liu, Z. H., Xie, Q. \& Gamian, A. (2004). Amycolatopsis palatopharyngis sp. nov., a potentially pathogenic actinomycete isolated from a human clinical source. Int J Syst Evol Microbiol 54, 359-363.

Kawato, M. \& Shinobu, R. (1959). On Streptomyces herbaricolor nov. sp. Supplement: a simple technique for the microscopic observation. Mem Osaka Univ Lib Arts Educ B 8, 114-119.

Kim, S. B. \& Goodfellow, M. (1999). Reclassification of Amycolatopsis rugosa Lechevalier et al. 1986 as Prauserella rugosa gen. nov., comb. nov. Int J Syst Bacteriol 49, 507-512.

Kim, B., Sahin, N., Tan, G. Y. A., Zakrzewska-Czerwinska, J. \& Goodfellow, M. (2002). Amycolatopsis eurytherma sp. nov., a thermophilic actinomycete isolated from soil. Int $J$ Syst Evol Microbiol 52, 889-894.

Kimura, M. (1980). A simple method for estimating evolutionary rates of base substitutions through comparative studies of nucleotide sequences. J Mol Evol 16, 111-120.

Kimura, M. (1983). The Neutral Theory of Molecular Evolution. Cambridge: Cambridge University Press. 
Kovács, N. (1956). Identification of Pseudomonas pyocyanea by oxidase reaction. Nature 178, 703-704.

Kumar, S., Tamura, K. \& Nei, M. (2004). MEGA3: integrated software for molecular evolutionary genetics analysis and sequence alignment. Brief Bioinform 5, 150-163.

Labeda, D. P., Donahue, J. M., Williams, N. M., Sells, S. F. \& Henton, M. M. (2003). Amycolatopsis kentuckyensis sp. nov., Amycolatopsis lexingtonensis sp. nov. and Amycolatopsis pretoriensis sp. nov., isolated from equine placentas. Int J Syst Evol Microbiol 53, 1601-1605.

Lechevalier, H. A. \& Lechevalier, M. P. (1980). The chemotaxonomy of actinomycetes. In Actinomycete Taxonomy, pp. 277-284. Society for Industrial Microbiology Special Publication no. 6. Edited by A. Dietz \& D. W. Thayer. Arlington, VA: Society for Industrial Microbiology.

Lechevalier, M. P., De Bièvre, C. \& Lechevalier, H. A. (1977). Chemotaxonomy of aerobic actinomycetes: phospholipid composition. Biochem Syst Ecol 5, 249-260.

Lechevalier, M. P., Prauser, H., Labeda, D. P. \& Ruan, J.-S. (1986). Two new genera of nocardioform actinomycetes: Amycolata gen. nov. and Amycolatopsis gen. nov. Int J Syst Bacteriol 36, 29-37.

Lee, S. D., Kinkel, L. L. \& Samac, D. A. (2006). Amycolatopsis minnesotensis sp. nov., isolated from a prairie soil. Int J Syst Evol Microbiol 56, 265-269.

Li, W. J., Xu, P., Schumann, P., Zhang, Y. Q., Pukall, R., Xu, L. H., Stackebrandt, E. \& Jiang, C. L. (2007). Georgenia ruanii sp. nov., a novel actinobacterium isolated from forest soil in Yunnan (China) and emended description of the genus Georgenia. Int J Syst Evol Microbiol 57, 1424-1428.

MacFaddin, J. F. (1980). Biochemical Tests for the Identification of Medical Bacteria, 2nd edn. Baltimore: Williams \& Wilkins.

Mertz, F. P. \& Yao, R. C. (1993). Amycolatopsis alba sp. nov., isolated from soil. Int J Syst Bacteriol 43, 715-720.

Mesbah, M., Premachandran, U. \& Whitman, W. B. (1989). Precise measurement of the $\mathrm{G}+\mathrm{C}$ content of deoxyribonucleic acid by highperformance liquid chromatography. Int J Syst Bacteriol 39, 159-167.

Minnikin, D. E., Collins, M. D. \& Goodfellow, M. (1979). Fatty acid and polar lipid composition in the classification of Cellulomonas, Oerskovia and related taxa. J Appl Bacteriol 47, 87-95.

Saintpierre-Bonaccio, D., Amir, H., Pineau, R., Tan, G. Y. A. \& Goodfellow, M. (2005). Amycolatopsis plumensis sp. nov., a novel bioactive actinomycete isolated from a New-Caledonian brown hypermagnesian ultramafic soil. Int J Syst Evol Microbiol 55, 2057 2061.

Saitou, N. \& Nei, M. (1987). The neighbor-joining method: a new method for reconstructing phylogenetic trees. Mol Biol Evol 4, 406425.
Shirling, E. B. \& Gottlieb, D. (1966). Methods for characterization of Streptomyces species. Int J Syst Bacteriol 16, 313-340.

Staneck, J. L. \& Roberts, G. D. (1974). Simplified approach to identification of aerobic actinomycetes by thin-layer chromatography. Appl Microbiol 28, 226-231.

Tamaoka, J., Katayama-Fujimura, Y. \& Kuraishi, H. (1983). Analysis of bacterial menaquinone mixtures by high performance liquid chromatography. J Appl Bacteriol 54, 31-36.

Tan, G. Y. A., Robinson, S., Lacey, E. \& Goodfellow, M. (2006a). Amycolatopsis australiensis sp. nov., an actinomycete isolated from arid soils. Int J Syst Evol Microbiol 56, 2297-2301.

Tan, G. Y. A., Ward, A. C. \& Goodfellow, M. (2006b). Exploration of Amycolatopsis diversity in soil using genus-specific primers and novel selective media. Syst Appl Microbiol 29, 557-569.

Tang, S.-K., Li, W.-J., Wang, D., Zhang, Y.-G., Xu, L.-H. \& Jiang, C.-L. (2003). Studies of the biological characteristics of some halophilic and halotolerant actinomycetes isolated from saline and alkaline soils. Actinomycetologica 17, 6-10.

Thompson, J. D., Gibson, T. J., Plewniak, F., Jeanmougin, F. \& Higgins, D. G. (1997). The CLUSTAL_X windows interface: flexible strategies for multiple sequence alignment aided by quality analysis tools. Nucleic Acids Res 25, 4876-4882.

Warwick, S., Bowen, T., McVeigh, H. P. \& Embley, T. M. (1994). A phylogenetic analysis of the family Pseudonocardiaceae and the genera Actinokineospora and Saccharothrix with 16S rRNA sequences and a proposal to combine the genera Amycolata and Pseudonocardia in an emended genus Pseudonocardia. Int J Syst Bacteriol 44, 293-299.

Wayne, L. G., Brenner, D. J., Colwell, R. R., Grimont, P. A. D., Kandler, O., Krichevsky, M. I., Moore, L. H., Moore, W. E. C., Murray, R. G. E. \& other authors (1987). International Committee on Systematic Bacteriology. Report of the ad hoc committee on reconciliation of approaches to bacterial systematics. Int J Syst Bacteriol 37, 463-464.

Yassin, A. F., Haggenei, B., Budzikiewicz, H. \& Schaal, K. P. (1993). Fatty acid and polar lipid composition of the genus Amycolatopsis: application of fast atom bombardment-mass spectrometry to the structure analysis of underivatized phospholipids. Int J Syst Bacteriol 43, 414-420.

Zhang, L., An, R., Wang, J., Sun, N., Zhang, S., Hu, J. \& Kuai, J. (2005). Exploring novel bioactive compounds from marine microbes. Curr Opin Microbiol 8, 276-281.

Zhang, L., Yan, K., Zhang, Y., Huang, R., Bian, J., Zheng, C., Sun, H., Chen, Z., Sun, N. \& other authors (2007). High-throughput synergy screening identifies microbial metabolites as combination agents for the treatment of fungal infections. Proc Natl Acad Sci U S A 104, 4606-4611. 